\title{
Inhibition of thecal androstenedione production by exogenous progesterone in the cyclic hamster*
}

\author{
F. Garza† and P. F. Terranova \\ Department of Physiology, Ralph L. Smith Research Center, \\ University of Kansas Medical Center, Kansas City, Kansas 66103, U.S.A.
}

\begin{abstract}
Summary. Implants of progesterone on the day of dioestrus II in the hamster induced on the following day an increase in circulating levels of progesterone $(6.0 \pm 0.7 \mathrm{ng} / \mathrm{ml}$, $\mathbf{N}=8$; sesame oil controls, $<0.5 \mathrm{ng} / \mathrm{ml}, \mathrm{N}=6$ ) and a decline in serum levels of $\mathrm{LH}$ $(5 \cdot 3 \pm 0.4 \mathrm{ng} / \mathrm{ml}$; controls $12 \pm 2 \mathrm{ng} / \mathrm{ml})$ and oestradiol $(10 \pm 2 \mathrm{pg} / \mathrm{ml}$; controls $69 \pm 5$ $\mathrm{pg} / \mathrm{ml})$. The production of androstenedione and oestradiol by antral follicles in vitro was reduced in progesterone-treated hamsters when compared with controls, but progesterone production was not affected. Aromatizing activities of antral follicles were the same in progesterone-treated and sesame oil-treated hamsters. Androstenedione production by theca was significantly less in progesterone-treated hamsters than in controls. On dioestrus II, LH replacement therapy ( $200 \mu \mathrm{g}$ ovine $\mathrm{LH}$ by osmotic minipump inserted s.c.) prevented the decline in follicular androstenedione and oestradiol production induced by progesterone alone, and also prevented the decline in thecal androstenedione production in vitro. The results indicate that exogenous progesterone on dioestrus II lowers circulating levels of $\mathrm{LH}$ by the following day, inhibits thecal androstenedione production and thus reduces follicular oestradiol production without alteration in aromatizing ability.
\end{abstract}

\section{Introduction}

Previous studies of the hamster have shown that large doses of progesterone administered on the day of oestrus or small doses of progesterone given on dioestrus II are highly effective in blocking ovulation (Greenwald, 1976, 1978, 1982). These studies have shown that, on dioestrus II, progesterone reduces circulating oestradiol and luteinizing hormone (LH) concentrations and thus disrupts the cyclic release of $\mathbf{L H}$ on the day of pro-oestrus. In addition, the acute effects of exogenous progesterone on the decline in oestradiol concentrations in serum were apparently mediated by a decrease in the circulating level of LH. Since LH controls thecal androgen production in developing and preovulatory follicles (Armstrong \& Dorrington, 1977) and maintains, in part, aromatizing activity in granulosa cells of the rat (Wang, Hsueh \& Erickson, 1981), the present study was designed to ascertain whether the progesterone-induced decline in oestradiol values was mediated by $\mathrm{LH}$ at the level of the theca, granulosa cell or both.

\section{Materials and Methods}

Cyclic hamsters were maintained in rooms at $22^{\circ} \mathrm{C}$ with a 14-h light and 10 -h dark daily lighting schedule. Food and water were available ad libitum. At 09:00-10:00 h on the day of dioestrus II

* Reprint requests to Dr P. F. Terranova.

$\dagger$ Present address: Department of Animal Science, Louisiana State University, Baton Rouge, LA 70803, U.S.A. 
hamsters were anaesthetized lightly with ether and a $10 \mathrm{~mm}$ incision was made through the skin. At that time a $14 \mathrm{~mm}$ Silastic elastomer implant $(0.062$ in. i.d. $\times 0.125$ in. o.d.: Dow-Corning Corp., Midland, Michigan, U.S.A.) containing $50 \mathrm{mg}$ progesterone $/ \mathrm{ml}$ sesame oil or sesame oil alone was inserted subcutaneously. On the following day (Day 4) at 09:00-10:00 h hamsters were decapitated, and blood was collected and kept at $4^{\circ} \mathrm{C}$ for $24 \mathrm{~h}$ : the serum was removed and frozen until assayed for progesterone, androstenedione, oestradiol, follicle-stimulating hormone (FSH) and LH. Also at the time of necropsy, 10 large preovulatory follicles/animal (6-8 animals/group) were carefully dissected in cold Medium TC-199 (GIBCO, Grand Island, NY, U.S.A.) using extra fine jeweller's forceps and a scalpel blade. The follicles were cleaned of any adhering interstitium. Three follicles per animal were incubated individually at $37^{\circ} \mathrm{C}$ for $3 \mathrm{~h}$ in $1 \mathrm{ml}$ Medium TC-199 containing $1 \mu \mathrm{g}$ ovine LH (NIH-LH-S22, 2.3 U/mg, $1 \mathrm{U}=1 \mathrm{mg}$ NIH-LH-S1 National Pituitary and Hormone Program, Baltimore, MD, U.S.A.) and 3 follicles/animal were incubated individually for $3 \mathrm{~h}$ with $270 \mathrm{ng}$ androstenedione in $1 \mathrm{ml}$ Medium TC-199. Four thecae/animal were prepared by incompletely bisecting the antral follicles and subjecting the follicular shells to mechanical agitation through a medicine dropper to remove granulosa cells as previously described (Terranova, Martin \& Chien, 1982); 4 thecae/animal were incubated individually with $1 \mu \mathrm{g}$ ovine $\mathrm{LH}$ for $3 \mathrm{~h}$ at $37^{\circ} \mathrm{C}$. At the end of the $3 \mathrm{~h}$ incubation, media were saved for steroid radioimmunoassay.

To determine the effects of exogenous $\mathrm{LH}$ on the progesterone-induced decline in oestradiol, cyclic hamsters were anaesthetized lightly with ether on the morning of dioestrus II at 09:00-10:00 $\mathrm{h}$ and animals were given s.c. implants for the following treatment groups: Group 1, a $14 \mathrm{~mm}$ progesterone implant elastomer and an Alzet osmotic minipump (No. 2001 Alza Corp, Palo Alto, CA, U.S.A.) containing $200 \mu \mathrm{g}$ ovine LH-S22 in $0.01 \mathrm{M}$-phosphate buffered saline (PBS), pH 7.0, with $0.1 \%$ bovine serum albumin (BSA); Group 2, a $14 \mathrm{~mm}$ progesterone implant and an Alzet minipump containing only BSA-PBS; Group 3, a $14 \mathrm{~mm}$ implant containing sesame oil and an osmotic minipump containing BSA-PBS. Hamsters were decapitated at 09:00-10:00 h on the day after dioestrus II and sera were saved for radioimmunoassay of progesterone, androstenedione and oestradiol. Also at that time, preovulatory follicles and thecae were incubated in vitro as described above.

\section{Radioimmunoassays}

Steroids. Assays were performed on sera and incubation media. Incubation samples contained Medium TC- 199 with $0 \cdot 1 \%$ BSA and were assayed without ether extraction. Antisera, tritiated steroids and standards were diluted with $0 \cdot 1 \mathrm{M}-\mathrm{PBS}$ in $0.1 \%$ gelatin (PBS-G), pH $7 \cdot 0$, and were added to $12 \times 75 \mathrm{~mm}$ glass disposable culture tubes in volumes of 100,100 and $20 \mu \mathrm{l}$ for the progesterone, androstenedione and oestradiol assays, respectively. Final incubation volumes were $220 \mu \mathrm{l}$. In each assay, parallelism was observed between known amounts of steroids in incubation media and the standard curve. Incubation media without steroids were the same as a 'zero' standard in each assay. In these assays equilibrium was attained after $60 \mathrm{~min}$ at room temperature $\left(22^{\circ} \mathrm{C}\right)$ or after an overnight incubation $(18 \mathrm{~h})$ at $4^{\circ} \mathrm{C}$. If the assays were performed at room temperature, after incubation for $1 \mathrm{~h}$, the tubes were chilled to $4^{\circ} \mathrm{C}$ by placing them in an ice bath and then the ice cold charcoal solution was added immediately. In both procedures, after the $20 \mathrm{~min}$ incubation with the charcoal (at $4^{\circ} \mathrm{C}$ ), the tubes were placed in a refrigerated centrifuge and centrifuged for $20 \mathrm{~min}$ at $1500 \mathrm{~g}$. After centrifugation, the supernatants were collected, placed in liquid scintillation vials with cocktail and counted. Details of the separation and counting procedures have been published (Terranova \& Greenwald, 1978).

Assays of sera for progesterone, androstenedione and oestradiol were similar to those described previously (Terranova \& Greenwald, 1978; Terranova, 1981). Standards in methanol and sera were diluted to $1 \mathrm{ml}$ with distilled water and then extracted with $2.0 \mathrm{ml}$ anhydrous diethyl ether. For progesterone, $10 \mu \mathrm{l}$ serum and $5 \mu \mathrm{l}(5 \cdot 0-800 \mathrm{pg})$ standard in methanol were assayed. For 
androstenedione, $25 \mu \mathrm{l}$ serum and $5 \mu \mathrm{l}(1.0-1000 \mathrm{pg})$ standard in methanol were assayed. For oestradiol, $300 \mu \mathrm{l}$ serum and $5 \mu \mathrm{l}(1 \cdot 0-800 \mathrm{pg})$ standard in methanol were assayed. The contents of each tube were extracted once with $2.0 \mathrm{ml}$ diethyl ether and the ether phase dried under reduced pressure with gentle mixing at $45^{\circ} \mathrm{C}$. Then appropriate antisera and radio-labelled steroid were added to the dry residue. The assays were incubated overnight at $4^{\circ} \mathrm{C}$ as described above.

In the progesterone assay, the progesterone antiserum (GDN 337) was provided by Dr G. D. Niswender (Colorado State University, Fort Collins, CO, U.S.A.). The lower limit of sensitivity was $5 \mathrm{pg} /$ tube and $\left[1,2,6,7-{ }^{3} \mathrm{H}\right]$ progesterone was the radiolabel. Results of the characterization of the anti-progesterone serum were not different from those previously reported by Gibori, Antczak \& Rothchild (1977). For the androstenedione assay the antiserum was provided by Dr J. A. Resko (Oregon Health Sciences University, Portland, OR, U.S.A.) and its characterization has been described (Terranova, 1981). The lower limit of assay sensitivity was $1 \mathrm{pg} / \mathrm{tube}$ and $[1,2,6,7-$ $\left.{ }^{3} \mathrm{H}\right]$ androstenedione was used for the radiolabel. In the oestradiol assay, antiserum was provided by Dr D. Collins (Emory University, Atlanta, GA, U.S.A.). Characterization of this antiserum was similar to that previously described (Wright, Collins \& Preedy, 1973) and this assay was sensitive to $2 \mathrm{pg} /$ tube. The radioligand was $\left[2,4,6,7-{ }^{3} \mathrm{H}\right]$ oestradiol- $17 \beta$. The coefficients for inter- and intraassay variation were $<8 \%$ for all three assays.

Gonadotrophins. FSH and LH were determined by radioimmunoassays using NIAMDD kits. The methods for these assays were similar to those described by Bast \& Greenwald (1974). The antisera used were anti-rat-FSH serum 10 and anti-rat LH-serum 3. Reference preparations used for standards were rat-FSH-RP1 $(2 \cdot 1 \times \mathrm{NIH-FSH-S1)}$ and LH-RP1 (0.03 $\times$ NIH-LH-S1). Iodinated preparations were rat FSH-I-3 and LH-I-6. In the FSH and LH assays $100 \mu \mathrm{l}$ sera were assayed. The coefficients of inter- and intra-assay variation were $<10.5 \%$ for these assays.

Statistics. Data were analyzed by Duncan's Multiple Range test and differences were considered significant if $P<0.05$.

\section{Results}

Progesterone implants installed on the morning of dioestrus II increased $(P<0.01)$ the serum concentration of progesterone by the next day when compared with the sesame oil group (Table 1). Serum concentrations of $\mathrm{LH}$ and oestradiol were significantly reduced but FSH was not affected (Table 1).

Table 1. Effects of progesterone or sesame oil implanted in hamsters on dioestrus II on serum concentrations of LH, FSH, progesterone and oestradiol the following day

\begin{tabular}{lccccc}
\hline \multicolumn{1}{c}{ Treatment } & $\begin{array}{c}\text { No. of } \\
\text { animals }\end{array}$ & $\begin{array}{c}\text { LH } \\
(\mathrm{ng} / \mathrm{ml})\end{array}$ & $\begin{array}{c}\text { FSH } \\
(\mathrm{ng} / \mathrm{ml})\end{array}$ & $\begin{array}{c}\text { Progesterone } \\
(\mathrm{pg} / \mathrm{ml})\end{array}$ & $\begin{array}{c}\text { Oestradiol } \\
(\mathrm{pg} / \mathrm{ml})\end{array}$ \\
\hline Sesame oil & 6 & $12 \pm 2$ & $189 \pm 17$ & $<0 \cdot 5$ & $69 \pm 5$ \\
Progesterone & 8 & $5 \cdot 3 \pm 0 \cdot 4^{*}$ & $171 \pm 29$ & $6 \cdot 0 \pm 0 \cdot 7^{*}$ & $10 \pm 2$ \\
\hline
\end{tabular}

Values are mean \pm s.e.m.

* $P<0.01$ when compared with value for sesame oil treatment.

Progesterone implants on dioestrus II reduced LH-stimulated androstenedione and oestradiol production by antral follicles in vitro on the following day, but progesterone production was unaffected (Table 2). The abilities of antral follicles to convert $270 \mathrm{ng}$ androstenedione to oestradiol were not statistically significantly different in the progesterone $(2710 \pm 149 \mathrm{pg}$ oestradiol/follicle/ $3 \mathrm{~h}, \mathrm{~N}=8)$ and sesame oil $(2266 \pm 196 \mathrm{pg}$ oestradiol/follicle $/ 3 \mathrm{~h}, \mathrm{~N}=6)$ groups. Thecal androstenedione production was lower $(P<0.01)$ in the progesterone-treated group $(1942 \pm 352$ $\mathrm{pg} /$ theca/3 h, $\mathrm{N}=8)$ when compared with the sesame oil-group $(6926 \pm 886 \mathrm{pg} /$ theca $/ 3 \mathrm{~h}, \mathrm{~N}=6)$. 
Table 2. Effects of progesterone or sesame oil implanted in hamsters on dioestrus II on in-vitro LH stimulated $(1 \mu \mathrm{g} \mathrm{LH} /$ follicle/ml $)$ steroid production $(\mathrm{pg} /$ follicle $/ 3 \mathrm{~h}$ ) by antral follicles on the following day

\begin{tabular}{lcccc}
\hline Treatment & $\begin{array}{c}\text { No. of } \\
\text { animals }\end{array}$ & Progesterone & Androstenedione & Oestradiol \\
\hline Sesame oil & 6 & $1802 \pm 282$ & $1816 \pm 283$ & $3521 \pm 665$ \\
Progesterone & 8 & $2435 \pm 362$ & $376 \pm 91(4)^{*}$ & $1213 \pm 313^{\mathrm{a}}$ \\
& \multicolumn{4}{c}{$<00(4)$} \\
\hline
\end{tabular}

Values are mean \pm s.e.m. Three follicles were incubated individually per animal.

${ }^{*} P<0.01$ when compared with value for sesame oil treatment.

Table 3. Effects of progesterone and LH replacement therapy ( $200 \mu \mathrm{g} \mathrm{LH}$ minipump) in hamsters on dioestrus II on in-vitro follicular steroidogenesis $(\mathrm{pg} /$ follicle/3 $\mathrm{h}$ ) the

following day

\begin{tabular}{lcccc}
\hline \multicolumn{1}{c}{ Treatment } & $\begin{array}{c}\text { No. of } \\
\text { animals }\end{array}$ & Progesterone & Androstenedione & Oestradiol \\
\hline Sesame oil + BSA pump & 8 & $1999 \pm 291$ & $1981 \pm 106$ & $3744 \pm 702$ \\
Progesterone + BSA pump & 6 & $2178 \pm 378$ & $391 \pm 80^{*}$ & $1109 \pm 213^{*}$ \\
Progesterone + LH pump & 6 & $2149 \pm 436$ & $3312 \pm 473^{*} \dagger$ & $5345 \pm 247^{*} \dagger$ \\
\hline
\end{tabular}

Values are mean \pm s.e.m. Three follicles were incubated individually per animal.

${ }^{*} P<0.05$ compared with value for sesame oil + BSA group.

$\dagger P<0.01$ compared with value for progesterone + BSA group.

Progesterone production by the thecae was not significantly different between the 2 groups (progesterone treated: $965 \pm 190 \mathrm{pg} /$ theca $/ 3 \mathrm{~h}, \mathrm{~N}=8$; sesame oil-treated: $803 \pm 187 \mathrm{pg} /$ theca $/ 3 \mathrm{~h}$, $N=6$ ). Oestradiol production by theca was $<100 \mathrm{pg} /$ theca $/ 3 \mathrm{~h}$.

LH replacement therapy (200 $\mathrm{gg}$ LH by minipump) in the progesterone-treated group significantly increased androstenedione and oestradiol production by antral follicles compared with sesame oil-BSA treated hamsters and progesterone-BSA treated hamsters (Table 3). Progesterone production by antral follicles in vitro was not statistically different among any group. Androstenedione production by theca from hamsters treated with $\mathrm{LH}$ and progesterone (14 $647 \pm$ $1334 \mathrm{pg} /$ theca/ $3 \mathrm{~h}, \mathrm{~N}=6)$ was higher $(P<0.01)$ than that in sesame oil-BSA-treated hamsters $(7077 \pm 602 \mathrm{pg} /$ theca $/ 3 \mathrm{~h}, \mathrm{~N}=6)$ and in progesterone-BSA-treated hamsters $(2010 \pm 282 \mathrm{pg} /$ theca $/ 3 \mathrm{~h}$ ).

\section{Discussion}

The present study has shown that exogenous progesterone inhibits thecal androstenedione production by lowering the circulating level of $\mathrm{LH}$; thecal progesterone production was unaffected by this treatment. Therefore, the thecal lyase and/or $17 \alpha$-hydroxylase enzymes might have been inhibited by the lowered LH. An unexpected finding was that thecal progesterone production was not reduced by exogenous progesterone; serum concentrations of LH were significantly lower in the progesterone-treated group when compared with sesame oil-treated hamsters (Table 1). Since it is well established that $\mathrm{LH}$ regulates the conversion of cholesterol to pregnenolone (Armstrong, 1968; Hall \& Young, 1968), then less pregnenolone should have been available for conversion to progesterone in the progesterone-treated group exhibiting low LH levels. Until pregnenolone production is measured no definite conclusion can be reached. LH replacement therapy prevented the decline in thecal androstenedione production induced by exogenous progesterone. In fact, the $200 \mu \mathrm{g}$ LH osmotic minipump increased thecal androstenedione production by 2-fold when 
compared with sesame oil- and BSA-treated hamsters. Possibly, a lower dose of LH in the osmotic minipump would have returned androstenedione production by the theca to levels observed in controls. Exogenous progesterone might also have increased the sensitivity of the theca to $\mathrm{LH}$ as observed in immature rats (Bogovich \& Richards, 1982; Richards \& Bogovich, 1982).

The decline in serum levels of LH (and the increase in circulating progesterone) did not alter the aromatizing ability of the follicle. FSH has been implicated as the major hormone controlling aromatase activity of the granulosa cells in rodents (Armstrong \& Dorrington, 1977), but LH has also been shown to maintain oestrogen production by granulosa cells (Wang et al., 1981) and by antral follicles (Shaban \& Terranova, 1983). On the morning after the start of progesterone treatment, the antral follicles were histologically 'normal' (data not shown) thus excluding the possibility of the onset of atresia. Since progesterone blocks ovulation for 1 or 2 days (Greenwald, 1978), continuous progesterone treatment may block ovulation day after day until progesterone treatment is withdrawn. Therefore continuous blockade of ovulation with progesterone might represent a model for study of the onset of atresia of antral follicles that were destined to ovulate on the day of oestrus.

The present study confirms that the theca is a major site of androstenedione synthesis in the hamster follicle (Makris \& Ryan, 1975) and that progesterone reduces circulating levels of oestradiol in the cyclic hamster (Greenwald, 1982). The acute decline in follicular oestradiol production induced by progesterone appears to be due to a lower circulating level of LH that induces a decline in thecal androstenedione production.

We thank the National Hormone and Pituitary Program for the supply of rat LH and FSH radioimmunoassay kits and ovine $\mathrm{LH}$. This research was supported by grants from NICHD (Nos $12754 \& 15526)$ and a Research Career Development Award NIH-K04-HD00478 to P.F.T.

\section{References}

Armstrong, D.T. (1968) Gonadotropins, ovarian metabolism and steroid biosynthesis. Recent Prog. Horm. Res. 24, 255-319.

Armstrong, D.T. \& Dorrington, J.H. (1977) Estrogen biosynthesis in the ovaries and testis. In Regulatory Mechanisms Affecting Gonadal Hormone Action, pp. 215-258. Eds J. A. Thomas \& R. H. Singhal. University Park Press, Baltimore.

Bast, J.D. \& Greenwald, G.S. (1974) Serum profiles of follicle-stimulating hormone, luteinizing hormone and prolactin during the estrous cycle of the hamster. Endocrinology 94, 1295-1299.

Bogovich, K. \& Richards, J.S. (1982) Androgen biosynthesis in developing ovarian follicles: evidence that luteinizing hormone regulates thecal $17 \alpha$-hydroxylase and $C_{17-20}$ lyase activities. Endocrinology 111, 12011208.

Gibori, G., Antezak, E. \& Rothchild, I. (1977) The role of estrogen in the regulation of luteal progesterone secretion in the rat after day 12 of pregnancy. Endocrinology 100, 1483-1495.

Greenwald, G.S. (1976) Exogenous progesterone: influence on ovulation and hormone levels in the cyclic hamster. J. Endocr. 73, 151-155.

Greenwald, G.S. (1978) Modification by exogenous progesterone of estrogen and gonadotropin secretion in the cyclic hamster. Endocrinology 103, 2315-2322.
Greenwald, G.S. (1982) Effects of multiple small doses of progesterone on estrogen and gonadotropin secretion in the cyclic hamster. Proc. Soc. exp. Biol. Med. 169, 189-192.

Hall, P.F. \& Young, D.G. (1968) Site of action of trophic hormones upon the biosynthetic pathways to steroid hormones. Endocrinology 82, 559-568.

Makris, A. \& Ryan, K.J. (1975) Progesterone, androstenedione, testosterone, estrone and estradiol synthesis in hamster ovarian follicle cells. Endocrinology 96, 694-701.

Richards, J.S. \& Bogovich, K. (1982) Effects of human chorionic gonadotropin and progesterone on follicular development in the immature rat. Endocrinology 111, 1429-1438.

Shaban, M.A. \& Terranova, P.F. (1983) Regulation of development of preovulatory follicles by FSH and LH in hypophysectomized hamsters. Endocrinology 112. Suppl., p. 300, Abstr. 879

Terranova, P.F. (1981) Steroidogenesis in experimentally induced atretic follicles of the hamster: a shift from estradiol to progesterone synthesis. Endocrinology $108,1885-1890$.

Terranova, P.F. \& Greenwald, G.S. (1978) Steroid and gonadotropin levels during the luteal-follicular shift of the cyclic hamster. Biol. Reprod. 18, 170175 . 
Terranova, P.F., Martis, N.C. \& Chien, S. (1982) Theca is the source of progesterone in experimentally induced atretic follicles of the hamster. Biol. Reprod. 26, 721727.

Wang, C., Hsueh, A.J.W. \& Erickson, G.F. (1981) LH stimulation of estrogen secretion by cultured rat granulosa cells. Molec. cell. Endocr. 24, 17-28.
Wright, K., Collins, D.C. \& Preedy, J.R.K. (1973) Comparative specificity of antisera raised against estrone, estradiol-17 $\beta$ and estriol using 6-O-carboxymethyloxime bovine serum albumin derivative. Steroids 21, 755-769.

Received 5 July 1983 